\title{
PENGARUH INTELLECTUAL CAPITAL TERHADAP KINERJA KEUANGAN PADA BANK GO PUBLIC YANG TERDAFTAR DI BURSA EFEK INDONESIA (BEI) \\ TAHUN 2009-2012
}

\author{
Hamidah \\ Fakultas Ekonomi, Universitas Negeri Jakarta \\ Email : hamidahsam@gmail.com \\ Dian Puspita Sari \\ Fakultas Ekonomi, Universitas Negeri Jakarta \\ Email : diandianps02@gmail.com \\ Umi Mardiyati \\ Fakultas Ekonomi, Universitas Negeri Jakarta \\ Email : umi.mardiyati@gmail.com
}

\begin{abstract}
The purpose of this study is to know the effect of intellectual capital on financial performance on bank go public listed on the Indonesia Stock Exchange in 20092012. The sampel are several bank go public. The research method in this study uses correlation study. The research model in this study employs panel data analysis with random effect approach on model la and fixed effect approach on model $1 b$. The empirical results show that intellectual capital that proxy with Value Added Capital Employed (VACA), Value Added Human Capital (VAHU) have positive significant effect on Earning per Share (EPS) but Structural Capital Value Added (STVA) has negative and no significant effect on Earning per Share (EPS). While, Value Added Capital Employed (VACA), Value Added Human Capital (VAHU) and Structural Capital Value Added (STVA) have positive significant effect on Return On Assets (ROA).
\end{abstract}

Keywords: Intellectual Capital, Value Added Capital Employed (VACA), Value Added Human Capital (VAHU), Structural Capital Value Added (STVA), Earning per Share (EPS), Return On Assets (ROA)

186 Hamidah \& Dian Puspita Sari 
Jurnal Riset Manajemen Sains Indonesia (JRMSI) | Vol. 5, No. 2, 2014

\section{PENDAHULUAN}

Memasuki era globalisasi, dunia bisnis memiliki tantangan yang sangat berat dan beragam. Para pelaku bisnis dituntut untuk menggunakan sumber da ya yang ada dengan efektif dan efisien. Kemampuan bersaing tidak hanya terletak pada kepemilikan aset berwujud, tetapi lebih pada inovasi, sistem informasi, pengelolaan organisasi dan sumber daya manusia yang dimiliki. Oleh karena itu, hal tersebut telah menyebabkan pergeseran paradigma dalam dimensi kehidupan manusia, yaitu dari paradigma lama yang hanya berfokus pada kekayaan fisik menjadi paradigma baru yang juga berfokus pada modal intelektual.

Modal intelektual dianggap sebagai sumber pengetahuan yang memiliki peran penting dalam peningkatan kekayaan perusahaan. Peran yang dimiliki modal intelektual tersebut mengakibatkan perkembangan teknologi semakin maju dan persaingan bisnis semakin kompetitif. Persaingan bisnis yang semakin kompetitif memaksa perusahaan untuk meningkatkan investasi dan pengelolaan aset yang berharga dan sukar ditiru agar tetap bisa bersaing dengan para pesaing.

Namun, keberadaan modal intelektual dalam laporan keuangan perusahaan masih belum jelas. Pengukuran yang tepat terhadap modal intelektual perusahaan belum dapat ditetapkan. Modal intelektual bersifat tidak berwujud dan non-fisik sehingga sulit untuk mengukurnya. Model akuntansi tradisional masih fokus pada aset fisik dan keuangan serta mengabaikan sebagian aset tidak berwujud. Kesulitan perusahaan untuk mencatat aktiva tidak berwujud dalam neraca juga dikarenakan standar akuntansi yang ada saat ini belum mampu mencatat dan melaporkan investasi yang dikeluarkan untuk memperoleh sumber daya non fisik (Partiwi dan Sabeni, 2005:694). Bahkan Standar Akuntansi Internasional atau Standar Pelaporan Keuangan Internasional (IAS/IFRS), yang baru saja dimodifikasi oleh Dewan Standar Akuntansi Internasional, tidak memberikan kontribusi untuk mendefinisikan konsep, prinsip dan metode penilaian aset IC (Zeghal et. al dalam Wibowo dan Sabeni, $2013: 2$ ). Di Indonesia, menurut Ulum et. al (2008:1) pedoman standar akuntansi hanya menjelaskan mengenai aktiva tidak berwujud saja bukan pencatatan modal intelektual yang terperinci. 
Pulic dalam Ulum (2009:88) telah mengembangkan suatu model yang dikenal dengan VAIC (Value Added Intellectual Coefficient). Model ini merupakan suatu model yang mengukur intellectual capital melalui nilai tambah yang dihasilkan melalui Value Added Capital Employed (VACA), Value Added Human Capital (VAHU) dan Structural Capital Value Added (STVA) yang dimiliki perusahaan.

Komponen pertama dari VAIC adalah capital employed (CE). CE merupakan modal keuangan, yaitu total modal yang digunakan untuk perolehan aset tetap dan aset lancar. Suatu perusahaan yang menggunakan dana yang tersedia lebih efisien dibandingkan perusahaan lain, maka dapat dikatakan bahwa perusahaan tersebut telah menunjukkan kemampuannya dalam mengelola serta menciptakan nilai tambah dari sumber daya modal yang dimilikinya. Dengan demikian, pengelolaan capital employed perusahaan secara efisien akan dapat meningkatkan kinerja perusahaan, sebaliknya jika capital employed dikelola secara tidak efisien maka dapat dikatakan bahwa perusahaan gagal dalam meraih kinerja yang baik.

Komponen kedua dari VAIC ini adalah human capital. Menurut, Bontis et. al dalam Ulum (2009:30), human capital dapat menunjukkan individual knowledge stock pada suatu organisasi. Human capital yang direpresentasikan melalui karyawannya merupakan kombinasi dari genetic inheritance, education, experience dan attitude dari kehidupan bisnisnya. Dengan adanya sumber daya manusia yang baik di dalam perusahaan tersebut, maka seharusnya perusahaan mempunyai keunggulan tersendiri dalam bekerja, bersaing dan merumuskan strategi yang lebih baik dalam menghadapi pesaing-pesaing mereka.

Komponen ketiga dari VAIC adalah structural capital (SC). SC meliputi seluruh non-human storehouses of knowledge dalam organisasi. Termasuk dalam hal ini adalah database, organisational charts, process manuals, strategies, routines dan segala hal yang membuat nilai perusahaan lebih tinggi dari pada nilai materialnya. Dengan memiliki struktur yang baik dalam organisasi, maka perusahaan memiliki pengendalian internal yang lebih baik sehingga dapat mendukung tercapainya tujuan organisasi perusahaan.

Berdasarkan latar belakang yang dikemukakan di atas, maka masalah penelitian ini dapat dirumuskan sebagai berikut: 
Jurnal Riset Manajemen Sains Indonesia (JRMSI) | Vol. 5, No. 2, 2014

1. Apakah Value Added Capital Employed (VACA), Value Added Human Capital (VAHU) dan Structural Capital Value Added (STVA) berpengaruh terhadap EPS?

2. Apakah Value Added Capital Employed (VACA), Value Added Human Capital (VAHU) dan Structural Capital Value Added (STVA) berpengaruh terhadap ROA?

Penelitian ini akan menguji pengaruh variabel-variabel independen yang meliputi Value Added Capital Employed (VACA), Value Added Human Capital (VAHU) dan Structural Capital Value Added (STVA) terhadap variabel dependen keuangan yang diproksikan dengan Earning per Share (EPS) dan Return On Assets (ROA).

\section{KAJIAN TEORI}

\section{Stakeholder Theory}

Berdasarkan teori stakeholder, manajemen organisasi diharapkan untuk melakukan aktivitas yang dianggap penting oleh stakeholder mereka dan melaporkan kembali aktivitas-aktivitas tersebut pada stakeholder. Tujuan utama dari teori stakeholder adalah untuk membantu manajer korporasi mengerti lingkungan stakeholder mereka dan melakukan pengelolaan dengan lebih efektif di antara keberadaan hubungan-hubungan di lingkungan perusahaan mereka. Namun demikian, tujuan yang lebih luas dari teori stakeholder adalah untuk menolong manajer korporasi dalam meningkatkan nilai dari dampak aktifitasaktifitas mereka dan meminimalkan kerugian-kerugian bagi stakeholder. Pada kenyataannya, inti keseluruhan teori stakeholder terletak pada apa yang akan terjadi ketika korporasi dan stakeholder menjalankan hubungan mereka.

\section{Legitimacy Theory}

Teori legitimasi berhubungan erat dengan teori stakeholder, teori legitimasi menyatakan bahwa organisasi secara berkelanjutan mencari cara untuk menjamin operasi mereka berada dalam batas dan norma yang berlaku di masyarakat. Menurut Deegan dalam Ulum (2009:7), dalam perspektif teori legitimasi, suatu perusahaan akan secara sukarela melaporkan aktifitasnya jika manajemennya 
menganggap bahwa hal ini adalah yang diharapkan oleh komunitas. Teori legitimasi bergantung pada premis bahwa terdapat "kontrak sosial" antara perusahaan dengan masyarakat di mana perusahaan tersebut beroperasi. Kontrak sosial adalah suatu cara untuk menjelaskan sejumlah besar harapan masyarakat tentang bagaimana seharusnya organisasi melaksanakan operasinya. Harapan sosial ini tidak tetap, namun berubah seiring berjalannya waktu. Hal ini menuntut perusahaan untuk lebih responsif terhadap lingkungan di mana mereka beroperasi (Deegan dalam Ulum, 2009:7).

\section{Resource Based Theory/Resource Based View (RBV)}

Resource Based Theory berpandangan bahwa perusahaan memperoleh keunggulan kompetitif dan kinerja keuangan yang baik dengan cara memiliki, menguasai dan memanfaatkan aset-aset strategis yang penting (Wernerfelt dalam Kumalasari dan Astika, 2011 :281). Resource Based Theory membahas mengenai kepemilikan sumber daya perusahaan dan bagaimana perusahaan mengelola sumber daya tersebut. Pengelolaan sumber daya yang efektif dan efisien oleh perusahaan dapat menciptakan keunggulan kompetitif sehingga dapat menghasilkan nilai perusahaan.

\section{Knowledge Based Theory}

Knowledge Based Theory membentuk dasar untuk membangun keterlibatan modal manusia dalam kegiatan rutin perusahaan. Hal ini dicapai melalui peningkatan keterlibatan karyawan dalam perumusan tujuan operasional dan jangka panjang perusahaan. Menurut Fleming dalam Wahdikorin (2010:10), pandangan berbasis pengetahuan adalah peran perusahaan mengembangkan pengetahuan baru yang penting untuk keuntungan kompetitif dari kombinasi unik yang ada pada pengetahuan. Dalam era persaingan yang ada saat ini, perusahaan sering bersaing dengan mengembangkan pengetahuan baru yang lebih cepat daripada pesaing mereka.

\section{Value Added Intellectual Coefficient (VAIC)}

Metode Value Added Intellectual Coefficient (VAIC) dikembangkan oleh Pulic pada tahun 1997 yang didesain menyajikan informasi tentang value creation efficiency dari aset berwujud (tangiable assets) dan aset tidak berwujud 
(intangiable assets) yang dimiliki perusahaan. Model ini dimulai dengan kemampuan perusahaan untuk menciptakan value added (VA). Value added adalah indikator yang sesuai untuk menilai keberhasilan bisnis dan menunjukkan kemampuan perusahaan dalam penciptaan nilai (Ulum, 2009:86).

VAIC adalah sebuah prosedur analitis yang dirancang untuk memungkinkan manajemen, pemegang saham dan pemilik kepentingan lain yang terkait untuk secara efektif memonitor dan mengevaluasi efisiensi nilai tambah atau value added (VA) dengan total sumber daya perusahaan dan masing-masing komponen sumber daya utama. Nilai tambah adalah perbedaan antara pendapatan (OUT) dan beban (IN).

Pendapatan (OUT) merepresentasikan revenue yang mencakup seluruh produk dan jasa yang dijual di pasar, sedangkan beban (IN) mencakup seluruh beban yang digunakan dalam memperoleh revenue. Hal yang terpenting dalam model ini adalah bahwa beban tenaga kerja (labour expenses) tidak termasuk dalam IN. Karena peran aktifnya dalam proses penciptaan nilai, labour expenses tidak dihitung sebagai biaya dan tidak masuk dalam komponen IN. Karena itu aspek kunci dalam Pulic adalah memperlakukan tenaga kerja sebagai faktor penciptaan nilai.

\section{Value Added Capital Employed (VACA)}

Value Added Capital Employed (VACA) merupakan indikator yang menunjukkan nilai tambah yang diciptakan oleh unit modal fisik. Pulic dalam Ulum (2009:87) mengasumsikan bahwa jika satu unit dari modal fisik menghasilkan return yang lebih besar dalam satu perusahaan daripada perusahaan yang lain, maka perusahaan tersebut lebih baik dalam menge lola modal fisiknya. Pengelolaan modal fisik secara efektif dan efisien merupakan bagian dari pemanfaatan modal intelektual perusahaan. Dengan menggunakan indikator VACA, maka dapat diketahui seberapa besar kemampuan perusahaan dalam memanfaatkan modal fisiknya.

\section{Value Added Human Capital (VAHU)}

Value Added Human Capital (VAHU) adalah indikator efisiensi nilai tambah modal manusia. VAHU merupakan rasio dari Value Added (VA) terhadap Human 
Capital (HC). Hubungan antara value added dan human capital mengindikasikan kemampuan dari HC untuk menciptakan nilai dalam perusahaan. Human capital akan meningkat jika perusahaan mampu mengoptimalkan pengetahuan yang dimiliki karyawan. Menurut Anatan dalam Wahdikorin (2010:13), human capital merupakan akumulasi nilai investasi yang tercermin dalam kegiatan pelatihan karyawan dan kompetensi sumber daya manusia. Human capital merupakan sumber daya perusahaan yang terdiri dari pengetahuan, keterampilan dan pengalaman yang dihasilkan melalui kompetensi, sikap dan kecerdasan intelektual (Partiwi dan Sabeni, 2005 :698).

\section{Structural Capital Value Added (STVA)}

Structural capital merupakan kemampuan organisasi dalam memenuhi proses rutinitas dan struktur perusahaan yang mendukung usaha karyawan untuk menghasilkan kinerja intelektual yang optimal dan kinerja bisnis secara keseluruhan (Sawarjuwono dan Kadir, 2003:38). Structural capital meliputi beberapa hal seperti sistem operasional, budaya organisasi, filosofi manajemen serta intellectual capital lain yang mempengaruhi proses kinerja karyawan. Perusahaan yang memiliki sumber daya karyawan yang baik jika tidak didukung dengan sistem yang bagus maka perusahaan tidak dapat mengoptimalkan potensi yang dimiliki karyawan.

\section{Earning per Share (EPS)}

Earning per Share (EPS) atau laba per saham adalah perbandingan antara pendapatan yang dihasilkan (laba bersih) dan jumlah saham yang beredar. EPS merupakan rasio yang mengukur seberapa besar dividen per saham yang akan dibagikan kepada investor setelah dikurangi dengan dividen bagi para pemilik perusahaan.

\section{Return On Assets (ROA)}

Return On Assets (ROA) merupakan perbandingan antara laba bersih dengan total aset yang dimiliki perusahaan. ROA yang positif menunjukkan bahwa total aktiva yang digunakan untuk beroperasi mampu memberikan laba kepada perusahaan. Sebaliknya, apabila ROA yang negatif menunjukkan bahwa total aktiva yang digunakan perusahaan mengalami kerugian (Harahap, 2009:305). 
Sehingga jika suatu perusahaan mempunyai ROA yang positif maka perusahaan tersebut berpeluang besar dalam meningkatkan pertumbuhan modal. Sebaliknya, jika suatu perusahaan mempunyai ROA yang negatif maka pertumbuhan modal perusahaan tersebut akan terhambat.

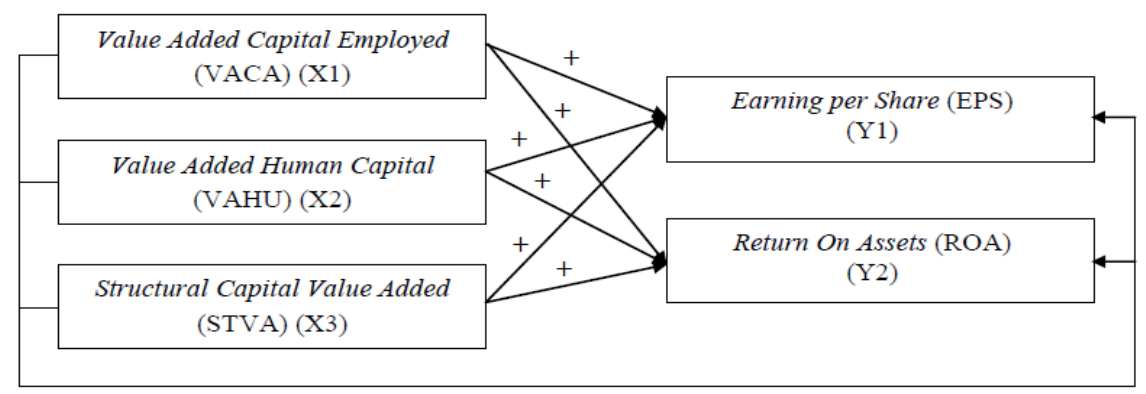

Gambar 1. Model Penelitian

Sumber : Data diolah peneliti (2014)

H1a: Value Added Capital Employed (VACA) berpengaruh positif terhadap Earning per Share (EPS)

H2a: Value Added Human Capital (VAHU) berpengaruh positif terhadap Earning per Share (EPS)

H3a: Structural Capital Value Added (STVA) berpengaruh positif terhadap Earning per Share (EPS)

H4a: VACA, VAHU dan STVA berpengaruh secara simultan terhadap Earning per Share (EPS)

H1b: Value Added Capital Employed (VACA) berpengaruh positif terhadap Return On Assets (ROA)

H2b: Value Added Human Capital (VAHU) berpengaruh positif terhadap Return On Assets (ROA)

H3b: Structural Capital Value Added (STVA) berpengaruh positif terhadap Return On Assets (ROA)

H4b: VACA, VAHU dan STVA berpengaruh secara simultan terhadap Return On Assets (ROA) 


\section{METODE PENELITIAN}

Metode yang digunakan dalam penelitian ini adalah correlational study yaitu untuk mengetahui hubungan antara dua variabel atau lebih dengan variabel lainya atau bagaimana suatu variabel mempengaruhi variabel lain. Metode analisis yang digunakan adalah metode regresi data panel.

Pengambilan sampel yang dilakukan dalam penelitian ini menggunakan metode purposive sampling. Teknik purposive sampling dilakukan dengan memilih sampel yang sesuai dengan kriteria - kriteria yang telah ditetapkan. Kriteria yang digunakan dalam pemilihan sampel adalah sebagai berikut:

1. Perusahaan perbankan dalam kategori Bank go public yang terdaftar di Bursa Efek Indonesia (BEI) selama bulan Januari 2009 sampai dengan Desember 2012.

2. Perusahaan perbankan yang menerbitkan laporannya selama 4 tahun berturut-turut.

Berdasarkan kriteria tersebut diatas, maka terpilihlah sampel sebanyak 23 bank go public yang terdaftar di Bursa Efek Indonesia (BEI) yang memberikan rincian rasio keuangan dari tahun 2009-2012.

Pengujian normalitas menggunakan uji statistik Jarque-Bera (JB). Pada hasil uji normalitas model 1a menunjukkan nilai probabilitas Jarque-Bera sebesar 0,234942. Dan model 1b menunjukkan nilai probabilitas Jarque-Bera sebesar 0,482709. Sehingga dengan hasil probabilitas Jarque-Bera pada model 1a dan model $1 \mathrm{~b}$ lebih besar dari 0,05 maka data tersebut telah terdistribusi dengan normal.

Pengujian multikolinearitas dapat dideteksi dengan menggunakan Pearson Correlation. Dari hasil pengujian tidak ada nilai korelasi yang lebih besar dari 0,8 sehingga data tidak mengalami multikolinearitas. Untuk mengetahui heteroskedastisitas pada penelitian ini menggunakan uji white. Apabila nilai probabilitas chi-square $>0,05$ maka dalam model tersebut tidak terdapat heteroskedastisitas. Hasil pengujian nilai obs*R-square pada model 1a sebesar 0,0779 dan pada model 1b sebesar 0,1487, yang menunjukkan nilai tersebut lebih besar dari 0,05 sehingga terbebas dari heterokedastisitas. Untuk mengetahui ada 
tidaknya autokorelasi digunakan Uji Breusch-Godfrey dengan melihat nilai probabilitas Obs*R-squared. Hasil probabilitas Obs*R-squared pada model 1a sebesar 0,1969 dan pada model 1b sebesar 0,1877 yang menunjukkan nilai tersebut lebih besar dari $\alpha(0.05)$ yang mengindikasikan bahwa data tidak mengandung masalah autokorelasi. Metode analisis pada penelitian ini dilakukan dengan program Eviews versi 7.

\section{HASIL DAN PEMBAHASAN}

\section{Analisis Deskriptif}

Analisis deskriptif yang digunakan dalam penelitian ini yaitu mean, median, maximum, minimum, dan standar deviasi. Pada tabel dibawah ini disajikan statistik deskriptif untuk VACA, VAHU dan STVA pada bank go public tahun 2009-2012.

Tabel 1. Statistik Deskriptif Variabel Penelitian Model 1a

\begin{tabular}{lcccc}
\hline \hline & VACA & VAHU & STVA & EPS (Rp.) \\
\hline \hline Mean & 0.321162 & 2.332403 & 0.427084 & 159.532 \\
Median & 0.300013 & 2.070717 & 0.517075 & 88.000 \\
Maximum & 0.787867 & 8.701447 & 0.885077 & 1240.000 \\
Minimum & 0.057070 & 0.174173 & -4.741429 & -14.770 \\
Std. Dev. & 0.137254 & 1.119233 & 0.605215 & 215.577 \\
Observations & 92 & 92 & 92 & 92
\end{tabular}

Sumber: Data diolah peneliti (2014)

Tabel 2. Statistik Deskriptif Variabel Penelitian Model $1 \mathrm{~b}$

\begin{tabular}{lcccc}
\hline \hline & VACA & VAHU & STVA & ROA (\%) \\
\hline \hline Mean & 0.323556 & 2.291543 & 0.438123 & $1.997 \%$ \\
Median & 0.300705 & 2.070717 & 0.517075 & $1.880 \%$ \\
Maximum & 0.787867 & 4.042625 & 0.752636 & $5.150 \%$ \\
Minimum & 0.057070 & 0.174173 & -4.741429 & $-1.880 \%$ \\
Std. Dev. & 0.137282 & 0.890367 & 0.597561 & $1.231 \%$ \\
Observations & 88 & 88 & 88 & 88 \\
Sumber: Data diolah peneliti (2014) & & &
\end{tabular}




\section{Analisis Regresi}

Tabel 3. Hasil Uji Regresi Model 1a

Dependent Variable: EPS

Method: Panel EGLS (Cross-section random effects)

Date: 05/03/14 Time: 14:17

Sample: 192

Periods included: 4

Cross-sections included: 23

Total panel (balanced) observations: 92

\begin{tabular}{crrrr}
\hline \hline \multicolumn{1}{c}{ Variable } & Coefficient & Std. Error & t-Statistic & Prob. \\
\hline \hline C & -67.52150 & 46.51023 & -1.451756 & 0.1501 \\
VACA & 536.7003 & 114.5839 & 4.683906 & 0.0000 \\
VAHU & 28.78243 & 11.89948 & 2.418798 & 0.0176 \\
STVA & -29.14379 & 19.00548 & -1.533441 & 0.1288 \\
\hline \hline & \multirow{2}{*}{ Weighted } & Statistics & \\
R-squared & 0.809263 & Mean dependent var & 52.98622 \\
Adjusted R-squared & 0.822988 & S.D. dependent var & 95.85449 \\
S.E. of regression & 85.57462 & Sum squared resid & 644425.4 \\
F-statistic & 18.25467 & Durbin-Watson stat & 1.174423 \\
Prob(F-statistic) & 0.000000 & & \\
\hline \hline
\end{tabular}

Sumber: Data diolah peneliti (2014)

Tabel 4. Hasil Uji Regresi Model 1 b

Cross-section fixed effects test equation:

Dependent Variable: ROA

Method: Panel Least Squares

Date: 03/21/14 Time: 20:29

Sample: 188

Periods included: 4

Cross-sections included: 23

Total panel (unbalanced) observations: 88

\begin{tabular}{crcrr}
\hline \hline \multicolumn{1}{c}{ Variable } & Coefficient & Std. Error & t-Statistic & Prob. \\
\hline \hline \multicolumn{1}{c}{ C } & -0.011425 & 0.001540 & -7.417102 & 0.0000 \\
VACA & 0.042594 & 0.004023 & 10.58823 & 0.0000 \\
VAHU & 0.007133 & 0.000688 & 10.37093 & 0.0000 \\
STVA & 0.002885 & 0.000971 & 2.971712 & 0.0039 \\
\hline \hline R-squared & 0.872302 & Mean dependent var & 0.019966 \\
Adjusted R-squared & 0.867742 & S.D. dependent var & 0.012315 \\
S.E. of regression & 0.004479 & A kaike info criterion & -7.934598 \\
Sum squared resid & 0.001685 & Schwarz criterion & -7.821991 \\
Log likelihood & 353.1223 & Hannan-Quinn criter. & 0.915537 \\
F-statistic & 191.2676 & Durbin-Watson stat & \\
Prob(F-statistic) & 0.000000 & & \\
\hline \hline
\end{tabular}

Sumber: Data diolah peneliti (2014) 
Jurnal Riset Manajemen Sains Indonesia (JRMSI) | Vol. 5, No. 2, 2014

1. Pengaruh Value Added Capital Employed (VACA) Terhadap Earning per Share (EPS)

Pada tabel 1 menunjukkan nilai koefisien dari variabel VACA adalah sebesar 536,7 satuan. Artinya, pengaruh VACA terhadap EPS arahnya adalah positif. Hal ini menandakan bahwa setiap kenaikan 1 satuan pada VACA maka EPS naik sebesar 536,7. Nilai probabilitas pada variabel VACA adalah 0,0000 < 0,05. Jadi, dapat disimpulkan VACA berpengaruh positif signifikan terhadap EPS. Hal ini menandakan rata-rata bank go public yang terdaftar di BEI pada periode tersebut sudah dapat memanfaatkan modal yang tersedia pada perusahaan secara optimal untuk meningkatkan kinerja keuangannya, sehingga EPS pun meningkat.

Sesuai dengan Stakeholder Theory, para stakeholder berkepentingan untuk mempengaruhi manajemen dalam proses pemanfaatan seluruh potensi yang dimiliki organisasi. Karena dengan pengelolaan yang baik dan maksimal atas seluruh potensi inilah organisasi akan dapat menciptakan value added untuk meningkatkan kinerja keuangan yang merupakan orientasi para stakeholder.

Hasil penelitian ini sesuai dengan penelitian yang dilakukan oleh Ritonga dan Andriyanie (2011), Salim dan Karyawaati (2013) yang menyatakan terdapat pengaruh yang positif signifikan terhadap EPS. Hal ini menunjukkan bahwa semakin besar VACA maka semakin tinggi laba per saham yang akan diperoleh perusahaan.

2. Pengaruh Value Added Human Capital (VAHU) Terhadap Earning per Share (EPS)

Nilai koefisien dari variabel VAHU adalah sebesar 28,78. Artinya, pengaruh VAHU terhadap EPS arahnya adalah positif. Hal ini menandakan bahwa setiap kenaikan 1 satuan pada VAHU maka EPS naik sebesar 28,78 satuan. Nilai probabilitas pada variabel VAHU adalah 0,0176 < 0,05. Jadi, dapat disimpulkan VAHU berpengaruh positif signifikan terhadap EPS. Hal ini menandakan 
rata-rata bank go public yang terdaftar di BEI pada periode tersebut mampu mendayagunakan sumber daya manusia untuk meningkatkan kinerja keuangannya, sehingga EPS pun meningkat. Hal ini menunjukkan bahwa semakin besar VAHU maka semakin tinggi laba per saham yang akan diperoleh perusahaan.

Sesuai dengan Resource Based Theory bahwa kemampuan perusahaan dalam mengelola sumber dayanya dengan baik dapat menciptakan keunggulan kompetitif sehingga dapat menciptakan nilai tambah bagi perusahaan.

Hasil penelitian ini sesuai dengan penelitian yang dilakukan oleh Ritonga dan Andriyanie (2011) yang menyatakan terdapat pengaruh yang positif signifikan terhadap EPS. Hal ini menunjukkan bahwa semakin besar VAHU maka semakin tinggi laba per saham yang akan diperoleh perusahaan. Namun hasil ini tidak sejalan dengan penelitian Salim dan Karyawati (2013) yang menyatakan bahwa VAHU tidak memiliki pengaruh yang signifikan terhadap EPS. Hasil penelitian ini menunjukkan fenomena yang mungkin disebabkan adanya hambatan infrastruktur yang menyebabkan berkurangnya motivasi untuk berinovasi.

\section{Pengaruh Structural Capital Value Added (STVA) Terhadap}

\section{Earning per Share (EPS)}

Nilai koefisien dari variabel STVA adalah sebesar -29,14. Artinya, pengaruh STVA terhadap EPS arahnya adalah negatif. Dengan demikian hipotesis 3 a ditolak. Hal ini menandakan bahwa setiap kenaikan 1 satuan pada STVA maka EPS turun sebesar -29,14 satuan. Nilai probabilitas pada variabel STVA adalah 0,1288>0,05. Jadi, dapat disimpulkan STVA berpengaruh negatif dan tidak signifikan terhadap EPS. Hal ini menandakan rata-rata bank go public yang terdaftar di BEI pada periode tersebut belum dapat meningkatkan pengetahuan para karyawannya dan mengembangkan 
Jurnal Riset Manajemen Sains Indonesia (JRMSI) | Vol. 5, No. 2, 2014

modal struktural yang dimilikinya dengan maksimal untuk meningkatkan kinerja keuangannya, sehingga EPS pun menurun.

Hasil penelitian ini tidak sesuai dengan Knowledge Based Theory yang menyatakan bahwa peran perusahaan mengembangkan pengetahuan baru yang penting untuk keunggulan kompetitif. Namun jika perusahaan tidak dapat mengembangkan pengetahuan baru maka perusahaan tersebut tidak dapat memperoleh keunggulan kompetiitif.

Hasil penelitian ini sesuai dengan penelitian yang dilakukan oleh Ritonga dan Andriyanie (2011) yang menyatakan tidak terdapat pengaruh yang signifikan terhadap EPS.

\section{Pengaruh Value Added Capital Employed (VACA) Terhadap Return On Assets (ROA)}

Pada tabel 2 nilai koefisien dari variabel VACA adalah sebesar 0,043. Artinya, pengaruh VACA terhadap ROA arahnya adalah positif. Hal ini menandakan bahwa setiap kenaikan 1 satuan pada VACA maka ROA naik sebesar 0,043 satuan. Nilai probabilitas pada variabel VACA adalah 0,0000 < 0,05. Jadi, dapat disimpulkan VACA berpengaruh positif signifikan terhadap ROA. Hal ini menandakan rata-rata bank go public yang terdaftar di BEI pada periode tersebut dapat memanfaatkan modal yang tersedia pada perusahaan secara optimal untuk meningkatkan kinerja keuangannya, sehingga ROA pun meningkat.

Sesuai dengan Stakeholder Theory, para stakeholder akan berupaya mengendalikan sumber daya yang dimiliki organisasi untuk meningkatkan kesejahteraan mereka. Kesejahteraan tersebut diwujudkan dengan semakin tingginya return yang dihasilkan organisasi.

Hasil penelitian ini sesuai dengan penelitian yang dilakukan oleh Wibowo dan Sabeni (2013) yang menyatakan terdapat pengaruh yang positif signifikan terhadap ROA. Hal ini menunjukkan bahwa semakin 
besar VACA maka semakin tinggi tingkat pengembalian aset yang akan diperoleh perusahaan.

5. Pengaruh Value Added Human Capital (VAHU) Terhadap Return On Assets (ROA)

Nilai koefisien dari variabel VAHU adalah sebesar 0,0071. Artinya, pengaruh VAHU terhadap ROA arahnya adalah positif. Hal ini menandakan bahwa setiap kenaikan 1 satuan pada VAHU maka ROA naik sebesar 0,0071 satuan. Nilai probabilitas pada variabel VAHU adalah $0,0000<0,05$. Jadi, dapat disimpulkan VAHU berpengaruh positif signifikan terhadap ROA. Hal ini menandakan rata-rata bank go public yang terdaftar di BEI pada periode tersebut mampu mendayagunakan sumber daya manusia untuk meningkatkan kinerja keuangannya, sehingga ROA pun meningkat.

Sesuai dengan Resource Based Theory bahwa perusahaan memperoleh keunggulan kompetitif dan kinerja keuangan yang baik dengan cara memiliki, menguasai dan memanfaatkan aset-aset strategis yang penting.

Hasil penelitian ini sesuai dengan penelitian yang dilakukan oleh Yusuf, Said dan Mediaty (2011) yang menyatakan terdapat pengaruh yang positif signifikan terhadap ROA. Namun hasil ini tidak sejalan dengan penelitian Aprilyani (2012) yang menyatakan bahwa VAHU tidak memiliki pengaruh yang signifikan terhadap ROA, hal disebabkan sedikitnya bank sampel yang digunakan sebagai penelitian sehingga hasil penelitian yang dihasilkan tidak mewakili bank yang ada di Indonesia.

6. Pengaruh Structural Capital Value Added (STVA) Terhadap Return On Assets (ROA)

Nilai koefisien dari variabel STVA adalah sebesar 0,0029. Artinya, pengaruh STVA terhadap ROA arahnya adalah positif. Hal ini menandakan bahwa setiap kenaikan 1 satuan pada STVA maka ROA naik sebesar 0,0029 satuan. Nilai probabilitas pada variabel 
Jurnal Riset Manajemen Sains Indonesia (JRMSI) | Vol. 5, No. 2, 2014

STVA adalah 0,0039<0,05. Jadi, dapat disimpulkan STVA berpengaruh positif signifikan terhadap ROA. Hal ini menandakan rata-rata bank go public yang terdaftar di BEI pada periode tersebut dapat mengelola modal struktural yang dimiliki perusahaan secara optimal untuk meningkatkan kinerja keuangannya, sehingga ROA pun meningkat.

Sesuai dengan Knowledge Based Theory yang menyatakan bahwa pengetahuan adalah salah satu sumber daya yang harus dikelola perusahaan agar memperoleh keunggulan kompetitif sehingga dapat meningkatkan return bagi perusahaan tersebut.

Hasil penelitian ini sesuai dengan penelitian yang dilakukan oleh Ulum, Ghozali dan Chairi (2008) dan Rambe (2012) yang menyatakan terdapat pengaruh yang positif signifikan terhadap ROA. Namun hasil penelitian ini tidak sejalan dengan penelitian Yusuf, Said dan Mediaty (2011) yang menyatakan tidak terdapat pengaruh yang signifikan terhadap ROA. Hal ini disebabkan penelitian Yusuf, Said dan Mediaty (2011) menggunakan variabel STVA sebagai variabel moderasi bagi variabel VAHU dengan ROA.

\section{KESIMPULAN DAN SARAN}

\section{Kesimpulan}

Berdasarkan hasil analisis data dan pembahasan yang telah dikemukakan dapat ditarik kesimpulan bahwa modal intelektual yang diproksikan dengan VACA, VAHU mempunyai pengaruh yang positif signifikan terhadap EPS namun STVA mempunyai pengaruh yang negatif dan tidak signifikan terhadap EPS pada bank go public yang terdaftar di BEI tahun 2009-2012. Sedangkan modal intelektual yang diproksikan dengan VACA, VAHU dan STVA mempunyai pengaruh yang positif signifikan terhadap ROA pada bank go public yang terdaftar di BEI tahun 2009-2012. 
Saran

Saran-saran yang dapat diberikan oleh peneliti untuk pihak perusahaan dan juga untuk peneliti selanjutnya adalah:

1. Bagi perusahaan perbankan diharapkan dapat mengelola sumber daya dan pengetahuan karyawan untuk menghasilkan kinerja yang baik bagi perkembangan perusahaan.

2. Bagi Ikatan Akuntan Indonesia (IAI) diharapkan dapat menetapkan standar yang lebih baik tentang pengungkapan intellectual capital dalam laporan keuangan.

3. Bagi peneliti selanjutnya, apabila akan melakukan penelitian lebih lanjut tentang tema yang sejenis, sebaiknya dalam penelitiannya menggunakan periode penelitian yang lebih lama agar lebih akurat. Kemudian menambahkan populasi yang lebih banyak dan tidak hanya menggunakan sampel perusahaan perbankan.

\section{DAFTAR RUJUKAN}

Aprilyani, Prima. 2012. Pengaruh Intellectual Capital Terhadap ROA pada Bank Negara Indonesia dan Bank Muamalat. Jurnal JEMI. Vol. 3, no.2. Universitas Maritim Raja Ali Haji.

Harahap, Sofyan Syafri. 2009. Analisis Kritis Atas Laporan Keuangan. Jakarta: Rajagrafindo Persada.

Kumalasari, Putu Diah dan Ida Bagus Putra Astika. 2011. Pengaruh Modal Intelektual Pada Kinerja Keuangan Di Bursa Efek Indonesia. (http://ojs.unud.ac.id/index.php/EEB/article/view/5178). Diakses pada tanggal 5 September 2013.

Partiwi, Dwi Astuti dan Arifin Sabeni. 2005. Hubungan Intellectual Capital dan Business Performance dengan Diamond Specification: Sebuah Perspektif Akuntansi. Simposium Nasional Akuntansi VIII Solo.

Rambe, Rizky Filhayati. 2012. Pengaruh Intellectual Capital Terhadap Kinerja Keuangan Perusahaan Perbankan yang Terdaftar di BEI. Jurnal Keuangan dan Bisnis. Vol. 4, No. 3, November 2011, pp: 239-246. 
Jurnal Riset Manajemen Sains Indonesia (JRMSI) | Vol. 5, No. 2, 2014

Ritonga, Kirmizi dan Jessica Andriyanie. 2011. Pengaruh Modal Intelektual Terhadap Kinerja Keuangan Pada Perusahaan LQ45 yang Terdaftar di Bursa Efek Indonesia. Pekbis Jurnal. Vol. 3, No. 2, Juli 2011, pp 467-481.

Salim, Selvi Meliza dan Golrida Karyawati. 2013. Pengaruh Modal Intelektual Terhadap Kinerja Keuangan. Journal of Business and Entrepreneurship. ISSN: 2302-4119, Vol. 1, No.2, Mei 2013, pp:1-13.

Sawarjuwono, Tjiptohadi dan Agustine Prihatin Kadir. 2003. Intellectual Capital: Perlakuan, Pengukuran dan Pelaporan (Sebuah Library Research). Jurnal Akuntansi \& Keuangan. Vol. 5, No.1, Mei 2003, pp:35-57.

Ulum, Ihyaul. 2008. Intellectual Capital Performance Sektor Perbankan di Indonesia. Jurnal Akuntansi dan Keuangan. Vol. 10, No. 2.

Ulum, Ihyaul, Imam Ghozali dan Anis Chairi. 2008. Intellectual Capital dan Kinerja Keuangan Perusahaan; Suatu Analisis Dengan Pendekatan Partial Least Squares. Simposium Nasional Akuntansi XI Pontianak.

Ulum, Ihyaul. 2009. Intellectual Capital: Konsep dan Kajian Empiris. Yogyakarta: Graha Ilmu.

Wahdikorin, Ayu. 2010. Pengaruh Modal Intelektual Terhadap Kinerja Keuangan Perusahaan Perbankan yang Terdaftar di Bursa Efek Indonesia (BEI) Tahun 2007-2009. Skripsi Universitas Diponegoro Semarang.

Wibowo, Eko dan Arifin Sabeni. 2013. Analisis Value Added Sebagai Indikator Intellectual Capital dan Konsekuensinya Terhadap Kinerja Perbankan. Journal of Accounting. Vol. 2, No. 1, 2013, pp:1-14.

Yusuf, Akbar, Darwis Said dan Mediaty. 2011. Hubungan Antara Modal Intelektual dengan Nilai Pasar dan Kinerja Keuangan di Perusahaan Publik Indonesia.

(http://pasca.unhas.ac.id/jurnal/files/49c4f845b017935c369ddb1824f6281. pdf). Diakses pada tanggal 5 September 2013. 